\title{
PERAN CONSCIENTIOUSNESS PERSONALITY TRAIT DAN IKLIM SEKOLAH DALAM PENCEGAHAN PERUNDUNGAN
}

\author{
Sri W. Rahmawati \\ Fakultas Psikologi, Universitas Tama Jagakarsa, Jl. TB Simatupang No 152, Jakarta 12530, Indonesia
}

Korespondensi:

e-mail:swrahma@yahoo.com

\begin{abstract}
The aim of this study was to examine the role of conscientiousness personaity trait and school climate toward bullying. A sample of 616 senior high school students from five regions in Jakarta were acquired for this study using cluster random sampling technique. The NEO PI-R Scale, The School Climate Scale, and The Scale of Bullying were used in this study. The research hypothesized that there would be a significant negative correlation between the personality trait and school goals and norms on bullying. The study found that conscientiousness personality trait and school goals and norms in school settings have significant negative correlations to bullying. Regression test results indicated that conscientiousness trait and school goals and norms contributed $4.2 \%$ and $3.8 \%$ on bullying. It was concluded that to obtain the optimal results, bullying prevention programs in schools should consider improving students' personality trait and the school climate.
\end{abstract}

Article history:

Received 12 January 2018

Received in revised form 18 January 2018

Accepted 15 April 2018

Available online 31 October 2018

Keywords:

bullying;

conscientiousness personality trait;

perpetrator;

school goal and norms

\begin{abstract}
Abstrak - Penelitian ini bertujuan untuk mengungkap peran trait kepribadian dan iklim sekolah terhadap perundungan. Riset terhadap 616 siswa yang berasal dari lima wilayah provinsi DKI Jakarta dilakukan dengan menggunakan teknik sampling kluster acak. Skala NEO PI-R, Skala Iklim Sekolah, serta Skala Perundungan digunakan sebagai alat ukur dalam penelitian ini. Hipotesis penelitian ini adalah terdapat hubungan negatif yang signifikan antara aspek (trait) kepribadian conscientiousness dan tujuan dan norma sekolah terhadap perundungan. Hasil riset membuktikan hipotesis yang telah ditegakkan, yaitu aspek kepribadian conscientiousness serta tujuan dan norma sekolah memiliki korelasi negatif yang signifikan terhadap perundungan. Hasil uji regresi menunjukkan bahwa sifat kepribadian conscientiousness memberikan kontribusi sebesar $4.2 \%$ terhadap perilaku perundungan pada siswa; sementara peran tujuan dan norma sekolah terhadap perundungan adalah sebesar $3.8 \%$. Dapat disimpulkan bila pencegahan perundungan di sekolah perlu memperhatikan pengembangan kepribadian siswa, maupun pembenahan iklim sekolah agar memeroleh hasil optimal.
\end{abstract}

Kata kunci: perundungan; kepribadian conscientiousness; pelaku; visi dan norma sekolah 


\section{PENDAHULUAN}

Perundungan di sekolah menjadi fenomena yang berkembang luas. Fenomena ini tidak hanya terjadi di Indonesia, namun juga dapat ditemui di berbagai negara. Hal tersebut mendorong berkembangnya penelitian perundungan di beberapa penjuru dunia seperti Australia, Belgia, Brazil, Kanada, China, Denmark, Inggris, Finlandia, Perancis, Korea Selatan, Turki, dan Amerika Serikat (Paramo, 2012).

Perundungan merupakan bentuk agresivitas sistematis yang dilakukan dengan memanfaatkan kekuatan tak berimbang antara pelaku terhadap korbannya, disertai dengan niat tertentu serta dilakukan secara berulang (Wolke \& Lereya, 2015). Pengertian perundungan yang tepat ini perlu digarisbawahi karena kecenderungan kesalahpahaman istilah yang terjadi di masyarakat Indonesia akhir-akhir ini (Rahmawati, 2016a). Pergeseran istilah perundungan yang kurang tepat ini berdampak pada minimalnya perhatian para pemangku kepentingan untuk mengatasi persoalan perundungan. Perundungan sendiri sebenarnya dapat terjadi pada berbagai situasi sosial, seperti di: tempat kerja, lingkungan pergaulan sosial sehari-hari, ataupun di kalangan para atlet. Namun, perundungan yang terjadi di sekolah umumnya mendapatkan sorotan secara khusus (Sullivan, 2000) dikarenakan fungsi sekolah sebagai lembaga pendidikan seyogianya bertanggung jawab dalam pembentukan karakter para siswanya.

Perundungan memiliki dampak yang serius, setidaknya dapat menyebabkan dua hal, yaitu jangka pendek dan jangka panjang. Dampak jangka pendek ialah takut pergi ke sekolah, perasaan tidak aman, merasa terisolasi, harga diri rendah, mengalami depresi hingga keinginan melakukan bunuh diri. Efek jangka panjang dapat berupa korban mengalami gangguan emosional dan kepribadian. Menurut Komisi Perlindungan Anak Indonesia (KPAI) terdapat kenaikan jumlah pelaku tindak agresivitas sepanjang tahun 2015 (“KPAI: Kasus bullying di sekolah,” 2015). Berdasarkan total kasus kekerasan di sekolah yang dihimpun, terdapat 79 kasus anak sebagai pelaku perundungan dan 103 kasus dengan anak sebagai pelaku tawuran. Kenaikan jumlah kasus tawuran termasuk yang cukup signifikan, yakni lebih dari 50 persen di tahun 2015 dibandingkan tahun 2014 lalu (Rahmawati, 2017).

Data-data yang diperoleh berkaitan dengan perundungan ini umumnya merupakan fenomena gunung es, di mana hal yang terjadi di bawahnya lebih besar lagi dan memengaruhi fungsi psikososial baik pelaku maupun korbannya (Rahmawati, 2016b). Adair dkk. (dalam Sullivan, 2000) 
melaporkan dalam penelitiannya bahwa perundungan yang dilaporkan hanya sekitar 21 persen, sementara 79 persen siswa yang pernah menjadi korban perundungan tidak melaporkan kejadian tersebut kepada guru ataupun orang tua mereka. Sebanyak 50 persen yang mengalami perundungan dinyatakan tidak dapat menghentikan ataupun memiliki strategi tertentu untuk menghentikannya.

Meskipun kasus perundungan di sekolah sudah sering terjadi, perundungan masih kurang banyak mendapatkan perhatian (Prasetyo, 2011). Hal tersebut dikarenakan tiga hal. Pertama, efeknya tidak dirasakan secara langsung, selain itu korbannya juga pada umumnya tidak melapor. Kedua, perundungan dianggap seperti interaksi khas biasa pada pergaulan anak-anak remaja sekarang yang diwarnai oleh ejekan dan olok-olok verbal. Pendidik biasanya tidak mengambil langkah lebih serius, kecuali dengan menegur pelakunya. Padahal luka psikologis dan emosional yang dialami korban dapat menimbulkan dampak yang berarti. Ketiga, sebagian orang tua dan guru tidak memiliki pengetahuan yang memadai mengenai perundungan dan dampaknya bagi kehidupan anak. Hal ini menyebabkan sebagian orang tua dan guru tidak menduga bila perundungan yang terjadi memiliki dampak yang serius di kemudian hari.

Tidak hanya korban perundungan yang memiliki persoalan kepribadian di masa depan (Ttofi, Farrington, Losel, \& Loeber, 2011), tetapi siswa yang menjadi pelaku perundungan juga merasakan dampaknya. Siswa pelaku perundungan di sekolah sering termasuk dalam kategori siswa bermasalah dan sering mendapatkan peringatan kedisiplinan dari sekolah. Pada masa yang akan datang, pelaku perundungan yang tidak tertangani ini akan terbiasa menggunakan perilaku agresif untuk memperoleh tujuan yang ingin diraih (Dunn, 2009). Pelaku juga cenderung akan melakukan tindakan kriminalitas di masa dewasa serta perilaku agresif lainnya, baik dalam lingkungan pekerjaan, dalam pernikahan, maupun dalam relasi sosial sehari-hari (Muth, 2012).

Memerhatikan dampak tersebut, dewasa ini telah banyak ditemukan penelitian perundungan yang memfokuskan pembahasannya pada pelaku perundungan. Namun riset-riset yang menyoroti aspek kepribadian pelaku perundungan masih jarang ditemui. Pelaku perundungan dicirikan memiliki karakteristik kepribadian tertentu seperti cenderung impusif, memiliki keinginan mendominasi orang lain, dan memperlihatkan sedikit empati terhadap para korbannya. Pelaku juga biasanya terlibat dalam tindakan agresif, kenakalan remaja, dan tindakan pelanggaran norma (Crapanzano, 2010). Pelaku umumnya pelaku menggunakan kekerasan untuk mencapai tujuan yang diinginkan dengan menyakiti atau membuat orang lain menderita (Kenneth, Barbara, Scott, \& Duane, 2008). Pelaku juga secara proaktif menunjukkan tingkah laku agresif sebagai bentuk antisipasi dari 
pencapaian tujuan yang ingin diraih (Dunn, 2009). Dapat disimpulkan bila kepribadian tertentu akan mendukung pelaku perundungan melakukan aksinya.

Kepribadian adalah bagaimana cara seseorang beradaptasi dalam lingkungan. Dalam penelitian ini, trait kepribadian merupakan hal yang diperkirakan berkorelasi dengan terbentuknya perilaku perundungan di sekolah. Para ahli psikologi kepribadian, melihat karakteristik kepribadian dipengaruhi oleh temperamen dasar seseorang. Allport (dalam Feist \& Feist, 2008), menyebutkan komponen dasar tersebut sebagai trait. Trait merupakan bagian inti yang koheren dari kepribadian. Trait merupakan potensi seseorang untuk berespons yang mengarahkan bentuk-bentuk perilaku yang konsisten. Trait memungkinkan tiap individu memberikan respons dengan cara yang berbeda terhadap berbagai stimulus, baik stimulus yang ada dalam diri maupun dari luar diri. Hal ini dikarenakan keunikan individu manusia yang akhirnya membuat para peneliti ingin mengadakan perubahan agar mereka dapat memiliki satu pemahaman yang sama tentang trait. Setelah bertahuntahun para peneliti dengan menggunakan metode modern, khususnya faktor analisis, sepakat untuk mengelompokkan perbedaan individu dalam lima hal besar yang disebut Big Five Trait Theory (McCrae \& Costa, 2003). Konsep trait Kepribadian Lima Besar (The Big Five Personality) ini merupakan pendekatan yang relatif sering digunakan dalam penelitian terhadap kepribadian manusia (Feist \& Feist, 2008; McCrae \& Costa, 2003).

Taksonomi lima besar merupakan evaluasi yang komprehensif dari kepribadian. Dalam penelitian kepribadian berdasarkan konsep lima besar ini, tidak dihasilkan suatu trait tunggal yang dimiliki seseorang secara dominan, tetapi masing-masing trait memberikan sumbangsih tersendiri terhadap perilaku tertentu. Pada studi pendahuluan yang dilakukan peneliti (Rahmawati, Iskandar, Setiono, \& Abidin, 2014), ditemukan hasil bahwa trait yang memiliki peran signifikan terhadap perudungan adalah agreeableness dan conscientiousness. Sementara ketiga trait lainnya pada studi pendahuluan yang telah dilakukan, menunjukkan korelasi yang tidak signifikan. Penelitian ini akan memfokuskan pada pengujian trait conscientiosness dengan populasi yang lebih luas, yaitu pada siswa SMA Negeri DKI Jakarta.

Conscientiousness dicirikan dengan sifat bersungguh-sungguh, bertanggung jawab, patuh terhadap peraturan, tekun, teratur, tepat waktu, pekerja keras, patuh terhadap prosedur, tergorganisir, serta berorientasi pada keberhasilan. Individu dengan trait conscientiousness yang kuat akan mengikuti norma yang menjadi acuan untuk mengelola dorongan impulsif yang dimiliki, terencana dalam bertindak, serta patuh pada aturan (Domenico, Quitasol, \& Fournier, 2015). Sifat- 
sifat ini merupakan kualitas personal positif yang menjadi salah satu tujuan pendidikan di sekolah, khususnya di masa SMA di mana pada usia tersebut remaja memiliki tugas perkembangan membentuk hati nurani. Nurani yang ditampilkan dalam bentuk kesungguhan sikap, kerja keras dan bertanggung jawab, sehingga diprediksi akan mengatasi remaja untuk melakukan perundungan terhadap rekan lainnya. Sementara individu dengan trait conscientiousness yang rendah akan muncul dalam bentuk perilaku mudah mengabaikan peraturan, kurang peduli pada keteraturan, ceroboh, dan cenderung mudah melakukan pelanggaran. Ciri-ciri yang disebutkan tersebut dapat ditemui sebagai besar pada pelaku perundungan. Gambaran ini memberikan deskripsi mengapa terdapat trait tertentu dalam tinjauan Kepribadian Lima Besar akan merepresentasikan faktor-faktor spesifik dari kepribadian pelaku perundungan.

Bila trait merepresentasikan variabel internal yang terdapat pada diri seseorang, maka terdapat pula stimulus eksternal yang diperkirakan akan mendukung siswa melakukan perundungan. Studi mengenai perundungan pada beberapa tahun terakhir ini menemukan variabel iklim sekolah sebagai faktor eksternal yang kerap menjadi pendorong terjadinya perundungan di sekolah-sekolah (Rolland \& Halloway, dalam Summers, 2008).

Pentingnya peran sekolah dalam mengatasi perundungan terlihat misalnya dari program Comitte for Children sejak tahun 2002. Dalam program intervensi the Steps to Respect Program, perundungan dikategorikan dalam beberapa tingkatan. Pelaksanaan program dimulai dengan membenahi iklim sekolah sebagai langkah utama. Dalam program tersebut, terkandung kebijakan untuk mengatasi perundungan dengan cara menumbuhkan kesadaran guru dan siswa terhadap perundungan, meningkatkan tanggung jawab terhadap faktor-faktor penyebab perundungan, dan dukungan untuk mengembangkan tingkah laku pro sosial (Hirschstein \& Frey, dalam Summers, 2008).

Sekolah yang sehat memiliki misi dan tujuan yang dipahami oleh setiap orang yang terlibat di dalamnya, baik guru maupun siswa. Namun pada sisi lain, salah satu ciri sekolah yang tidak sehat adalah bila misi dan tujuan sekolah ditentukan oleh orang tua atau masyarakat (Waasdorp, Bradshaw, \& Duong, 2011).

Iklim sekolah merupakan persepsi sosial terhadap lingkungan yang terdapat di sekolah pada tiga dimensi berikut. Pertama, iklim sekolah merupakan faktor kontekstual yang memengaruhi pembelajaran dan perkembangan siswa di sekolah. Kedua, iklim sekolah relatif stabil dari waktu ke waktu. Ketiga, iklim sekolah dapat dirasakan bermakna bagi banyak warga yang terlibat di 
dalamnya. Pengertian iklim sekolah ini lebih merujuk kepada persepsi terhadap lingkungan sosial yang dimiliki guru, siswa, maupun staf akademik lainnya di sekolah, dibandingkan dengan keadaan objektifnya (Sutherland, 2010). Iklim sekolah merupakan 'jantung' dan 'roh' sekolah, yang membuat seorang guru ataupun siswa memiliki perasaan tertentu pada sekolahnya, seperti perasaan senang atau justru sebaliknya (Ryan, 2009). Sekolah yang memiliki iklim yang positif akan mengundang guru dan siswa merasa nyaman berada di dalamnya dan mendorong mereka untuk menampilkan kemampuan terbaiknya (Jimerson, Swearer, \& Espelage, 2009). Siswa akan termotivasi untuk menunjukkan pencapaian akademik dan di sisi yang lain tidak berminat pada aktivitas agresif.

Terdapat beberapa komponen iklim sekolah untuk mengurangi perilaku perundungan. Namun, penelitian ini akan membatasi pada satu komponen penting utama dalam iklim sekolah yaitu tujuan dan norma sekolah (school goals and norms). Komponen ini berfokus pada aturan dan kebijakan yang berlaku di sekolah yang ditegakkan dalam memandu warga sekolah menjalankan perannya. Aturan sekolah yang dijalankan secara konsisten akan mendatangkan kepastian dan rasa nyaman warga sekolah.

Berdasarkan penjelasan di atas, maka tujuan dari penelitian ini adalah menguji kontribusi aspek (trait) kepribadian conscientiousness dan tujuan dan norma sekolah terhadap perundungan. Hipotesis yang diajukan peneliti adalah: 1) conscientiousness memiliki korelasi negatif yang signifikan terhadap perundungan dan 2) tujuan dan norma sekolah memiliki kontribusi dalam mencegah perundungan di sekolah.

\section{METODE}

\section{Partisipan}

Populasi dari penelitian ini adalah siswa SMA di DKI Jakarta. Populasi ini dipilih karena DKI Jakarta adalah ibu kota negara Indonesia. Setiap peristiwa, kejadian, dan fenomena yang berlangsung pada siswa di kota ini akan dengan mudah diasumsikan sebagai cermin dari gambaran remaja Indonesia, terutama di kota-kota besar. Oleh karena populasinya yang luas, maka peneliti mengambil sampel dengan menggunakan teknik cluster random sampling (Kerlinger \& Lee, 2006). Satu kecamatan dari lima wilayah ibu kota, yaitu Jakarta Selatan, Jakarta Timur, Jakarta Barat, Jakarta Utara, dan Jakarta Pusat, masing-masing dipilih secara acak. Setelah itu, dipilih satu SMA 
pada kecamatan yang dimaksud. Partisipan dalam penelitian ini berjumlah 616 siswa SMA, terdiri dari 228 siswa laki-laki dan 388 siswa perempuan. Kontrol terhadap sampel penelitian dilakukan dengan menyetarakan karakteristik sampel, yaitu keseluruhannya berasal dari sekolah negeri (atau SMAN) dengan pertimbangan bahwa sekolah-sekolah ini memiliki standarisasi yang kurang lebih serupa dalam proses penerimaan siswa, rasio jumlah guru dan siswa, luas sekolah, penegakkan aturan di sekolah, serta prestasi sekolah. Hal ini diprediksikan memengaruhi terbentuknya iklim sekolah tertentu di sekolah, termasuk dalam hal penegakkan aturan sekolah terhadap bentuk-bentuk pelanggaran, seperti melakukan tindakan perundungan.

\section{Desain}

Penelitian ini menggunakan pendekatan kuantitatif. Pendekatan ini digunakan karena adanya dua pertimbangan. Pertama, dalam penelitian ini isu yang diangkat dapat digunakan untuk menerangkan fenomena yang dialami masyarakat luas (dalam penelitian ini adalah siswa SMA), sehingga dibutuhkan banyak subyek sebagai sampel penelitian. Kedua, penelitian ini membutuhkan adanya uji hipotesa yang digunakan untuk menguji hubungan antar variabel. Penelitian ini tidak melakukan manipulasi variabel sebagaimana penelitian eksperimental (experimental research), tetapi menjelaskan variabel bebas (independent variable) terhadap variabel tergantung (dependent variable). Dapat disimpulkan bila penelitian ini tergolong sebagai studi explanatory yang pengukuran variabel-variabel penelitiannya didasarkan pada kondisi ex post facto, yaitu mengukur aspek-aspek psikologis yang ada dalam diri subyek pada suatu waktu tertentu.

\section{Prosedur}

Setelah memperoleh izin dari Dinas Pendidikan terkait serta pimpinan sekolah, pengambilan data dilakukan selama kurang lebih 1 bulan. Siswa yang dijadikan responden adalah siswa kelas XI SMA dengan pertimbangan mereka sudah mengenal lebih dekat teman-teman sekolahnya, dibandingkan siswa kelas X SMA. Selain itu, mereka juga belum disibukkan dengan persiapan Ujian Nasional sebagaimana siswa kelas XII SMA.

\section{Instrumen}

Alat ukur yang digunakan dalam penelitian in adalah kuesioner yang diadaptasi dari skala NEO PI-R (McCrae \& Costa, 2003), khusus pada butir-butir yang menggali conscientiousness. 
Faset dalam conscientiousness meliputi: tanggung jawab (responsible), hati-hati (careful), teratur (orderly), orientasi prestasi (achievement oriented), konsisten menjalankan peraturan (preserving), dan memiliki pertimbangan matang (thorough).

Alat ukur berikutnya adalah Skala Iklim Sekolah yang dikembangkan dari skala School Social Competence Development (Orpinas \& Horne, dalam Jimerson dkk., 2009), terdiri dari 10 butir yang fokus pada pengukuran tujuan dan norma sekolah.

Sementara alat ukur perundungan dalam penelitian ini difokuskan pada pelaku perundungan (bullyers) dengan menggunakan Skala Perundungan yang diadaptasi dari My Life at School Checklist (Arora, 1994). Alat ukur ini telah digunakan secara luas dalam mengukur perundungan di sekolah.

Ketiga alat ukur, baik skala NEO PI-R, Skala Iklim Sekolah, serta Skala Perundungan dirancang dengan menggunakan skala Ordinal dan pilihan rentang jawaban antara 1 (sangat tidak sesuai) sampai dengan 6 (sangat sesuai).

Sebelum digunakan, ketiga alat ukur telah melalui proses uji validitas. Setelah itu dilakukan uji reliabilitas terhadap pernyataan yang sudah valid. Pengujian dilakukan dengan menggunakan konsistensi internal Cronbach alpha dan memperoleh hasil sebesar $\alpha=.741, \alpha=.711$ dan $\alpha=.861$ berturut-turut untuk Skala NEO PI-R, Skala Iklim Sekolah, dan Skala Perundungan. Hasil perhitungan tersebut menunjukkan bahwa alat ukur memiliki tingkat reliabilitas yang tergolong pada kategori tinggi dan tinggi sekali (Guilford, 1978), sehingga layak digunakan dalam penelitian.

\section{Teknik Analisis}

Pengujian variabel-variabel dalam penelitian ini menggunakan teknik analisis uji korelasi dan uji regresi. Uji korelasi digunakan untuk melihat keterkaitan antara variabel penelitian. Sementara metode regresi digunakan untuk melihat pengaruh antara variabel penelitian.

\section{ANALISIS DAN HASIL}

Tabel 1 menjelaskan perhitungan deskriptif dari variabel-variabel penelitian yang diuji dengan menggunakan serangkaian teknik statistik. 
Tabel 1.

Partisipan Penelitian Berdasarkan Asal Sekolah

\begin{tabular}{|c|c|c|c|c|c|c|c|c|c|}
\hline \multirow{3}{*}{ No } & \multirow{3}{*}{ Wilayah } & \multirow{3}{*}{ Kecamatan } & \multirow{3}{*}{$\begin{array}{c}\text { Nama } \\
\text { Sekolah }\end{array}$} & \multicolumn{6}{|c|}{ Responden } \\
\hline & & & & \multicolumn{2}{|c|}{ Laki-laki } & \multicolumn{2}{|c|}{ Perempuan } & \multicolumn{2}{|c|}{ Jumlah } \\
\hline & & & & f & $\%$ & $\mathbf{f}$ & $\%$ & f & $\%$ \\
\hline 1 & Jakarta Utara & Kelapa Gading & SMA A & 42 & 40 & 62 & 60 & 104 & 100 \\
\hline 2 & Jakarta Barat & Tambora & SMA B & 42 & 34 & 82 & 66 & 124 & 100 \\
\hline 3 & Jakarta Pusat & Sawah Besar & SMA C & 18 & 30 & 42 & 70 & 60 & 100 \\
\hline 4 & Jakarta Timur & Cijantung & SMA D & 55 & 32 & 117 & 68 & 172 & 100 \\
\hline \multirow[t]{2}{*}{5} & Jakarta Selatan & Cilandak & SMA E & 71 & 46 & 85 & 54 & 156 & 100 \\
\hline & & & TOTAL & 228 & 45 & 388 & 54 & 616 & 100 \\
\hline
\end{tabular}

Jumlah siswa perempuan dalam penelitian ini terdiri dari 388 siswa (54\%), sementara jumlah siswa laki-laki adalah 228 orang (45\%). Sebaran siswa pada masing-masing wilayah ibu kota adalah Jakarta Utara (42 siswa laki-laki dan 62 siswa perempuan), Jakarta Barat (42 siswa lakilaki dan 88 siswa perempuan), Jakarta Pusat (18 siswa laki-laki dan 42 siswa perempuan), Jakarta Timur (55 siswa laki-laki dan 117 siswa perempuan), dan Jakarta Selatan (71 siswa laki-laki dan 85 siswa perempuan).

Data berikutnya di bawah ini adalah gambaran trait conscientiousness yang dimiliki partisipan baik dari jenis kelamin laki-laki maupun perempuan.

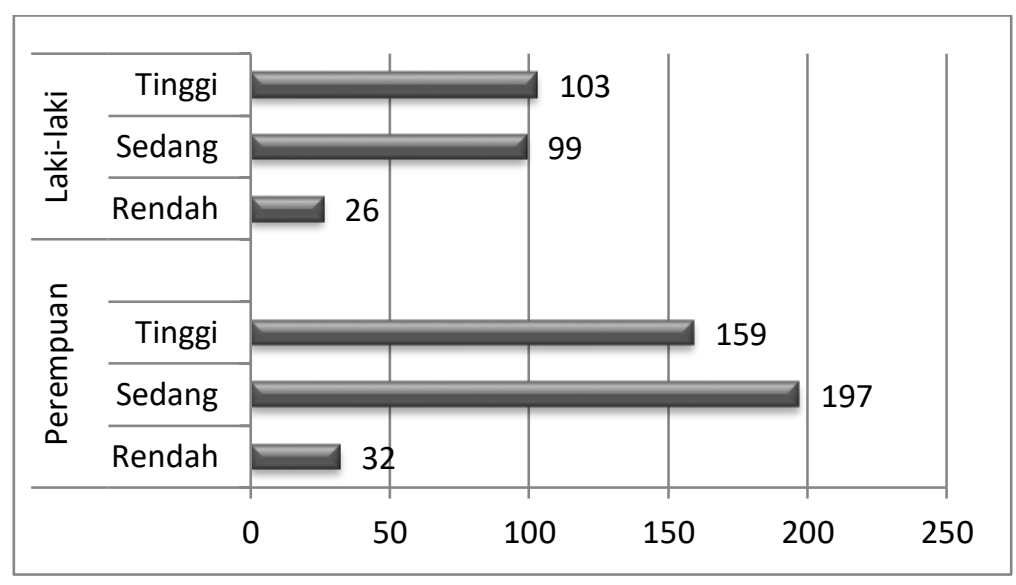

Figur 1. Conscientiousness Trait Antara Siswa Laki-Laki dan Perempuan

Peneliti membagi conscientiousness partisipan dalam tiga kategori, yaitu rendah (skor antara 1.00 sampai 2.66), sedang (antara 2.67 sampai 4.33), dan tinggi (antara 4.34 sampai 6.00). Berdasarkan klasifikasi tersebut, maka terlihat pada Figur 1 bahwa mayoritas siswa laki-laki menilai concientiousness yang mereka miliki pada kategori tinggi $(n=103)$, diikuti dengan kategori 
menengah $(n=99)$, dan kemudian rendah $(n=26)$. Sementara pada siswa perempuan, mayoritas siswa menilai trait ini dalam kategori sedang $(n=197)$, diikuti dengan kategori tinggi $(n=159)$, dan terakhir rendah $(n=32)$.

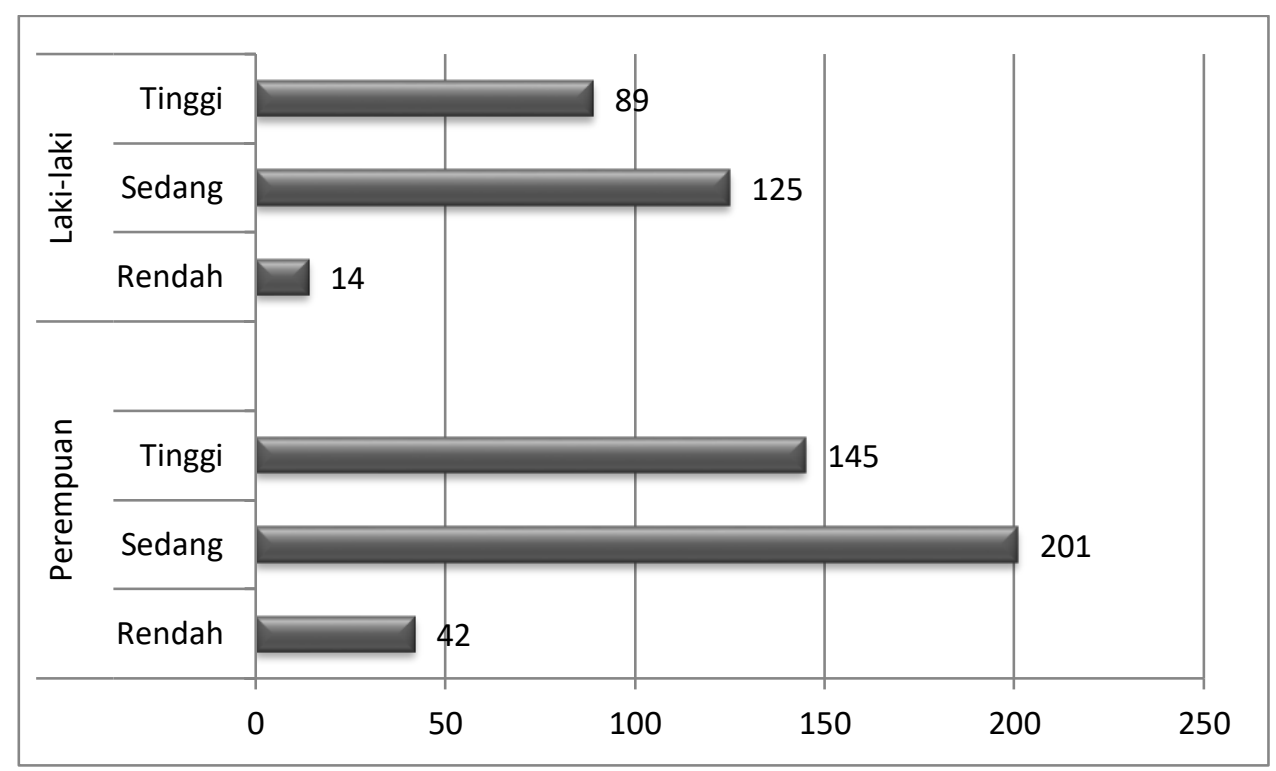

Figur 2. Penyebaran Skor Tujuan dan Norma Sekolah antara Siswa Laki-Laki dan Perempuan

Selanjutnya pada Figur 2 di atas peneliti juga melakukan pengelompokkan skor rata-rata tujuan dan norma sekolah partisipan ke dalam tiga klasifikasi, yaitu rendah (nilai $M$ antara 1 sampai 2.66), sedang (antara 2.67 hingga 4.33), dan tinggi (antara 4.34 hingga 6.00). Berdasarkan informasi yang didapatkan menunjukkan bahwa mayoritas siswa laki-laki menilai kualitas tujuan dan norma sekolah pada kategori sedang $(n=125)$, sementara sisanya memberikan penilaian pada kategori tinggi $(n=89)$, dan rendah $(n=14)$. Sejalan dengan pola tersebut, mayoritas siswa perempuan juga memberikan penilaian sedang pada kualitas tujuan dan norma sekolah $(n=201)$, diikuti dengan penilaian tinggi $(n=145)$, dan rendah $(n=42)$. 


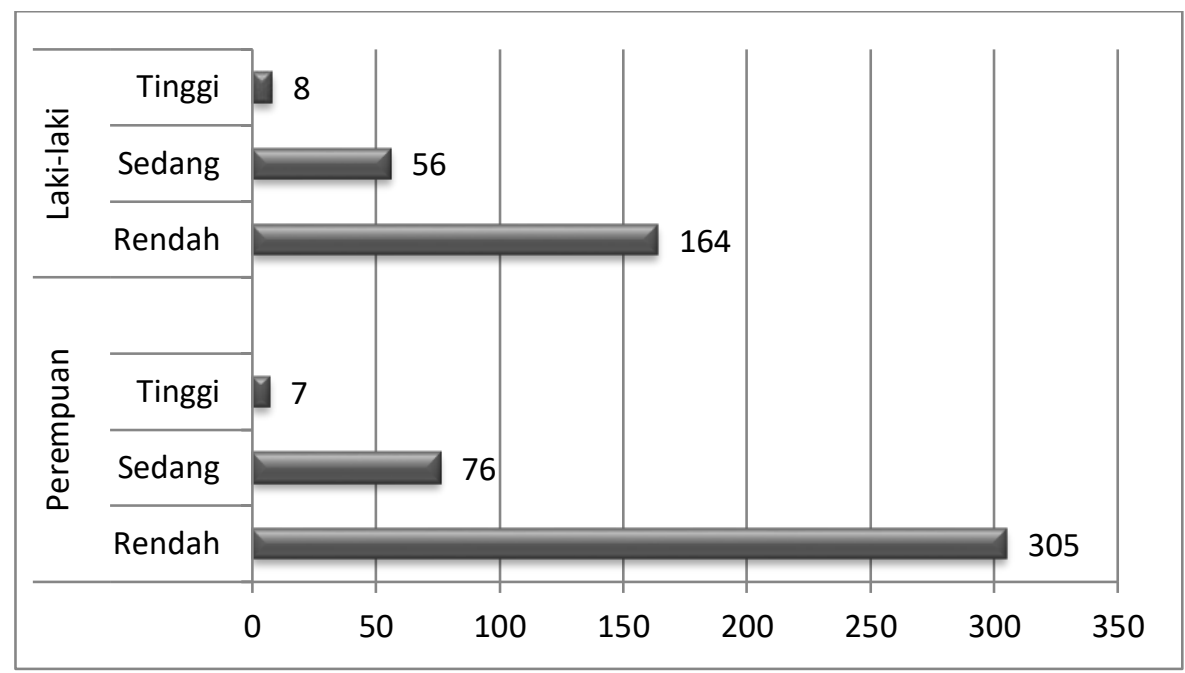

Figur 3. Penyebaran skor pelaku perundungan antara siswa laki-laki dan perempuan

Serupa dengan variabel lainnya, peneliti membagi skor rata-rata pelaku perundungan ke dalam tiga kategori, dimana partisipan yang memiliki mean antara 1 sampai 2.66 di kategorikan ke dalam kelompok dengan kategori rendah, partisipan yang memiliki mean antara 2.67 hingga 4.33 masuk ke dalam kategori sedang, dan partisipan yang memiliki mean antara 4.34 hingga 6.00 tergolong memiliki kategori pelaku perundungan tinggi. Berdasarkan kategorisasi tersebut, pada Figur 3 di atas terlihat sebanyak 164 siswa laki-laki memiliki penilaian yang rendah, diikuti dengan penilaian sedang dari 56 siswa, dan terakhir penilaian tinggi dari 8 siswa. Siswa perempuan juga menunjukkan pola penilaian yang sama, dimana 305 siswa menilai perundungan aspek pelaku mereka rendah, sementara 76 memberikan penilaian sedang, dan 7 siswa lainnya menilai dalam level yang tinggi.

Hasil uji berikutnya melihat hubungan antara trait conscientiousness maupun tujuan dan norma sekolah terhadap perundungan pada tabel di bawah ini:

Tabel 2.

Nilai Rerata, Range Skor, Pearson Correlation

\begin{tabular}{cccccc}
\hline No & Variabel & $M$ & $S D$ & Range & $r$ \\
\hline 1 & Conscientiousness & 41.597 & 10.130 & $10-60$ & $-.205^{* *}$ \\
\hline 2 & $\begin{array}{c}\text { School Goal } \\
\text { and Norms }\end{array}$ & 36.636 & 11.912 & $10-60$ & $-.194^{* *}$ \\
\hline
\end{tabular}

Keterangan: $* *$ Korelasi signifikan pada tingkat 0.01 (2-tailed)

Berdasarkan Tabel 2, diperoleh data bahwa trait conscientiousness yang ditandai oleh karakteristik sifat bersungguh-sungguh, bertanggung jawab, patuh pada prosedur, tekun, teratur, 
tepat waktu, dan terorganisir, memiliki korelasi signifikan dengan arah negatif terhadap perundungan $(r=-.205, p<.01)$. Artinya semakin tinggi trait conscientiousness pada diri siswa, maka semakin kecil kemungkinan ia akan menjadi pelaku perundungan. Selain itu, hasil uji korelasi antara tujuan dan norma sekolah terhadap perundungan berkorelasi signifikan dengan arah negatif $(r=-.194, p<.01)$. Hasil uji korelasi tersebut mengindikasikan bahwa semakin tinggi tujuan dan norma sekolah yang dipersepsi siswa dari sekolahnya, maka akan semakin rendah kemungkinan siswa untuk menjadi pelaku perundungan.

Tabel berikut dapat menjelaskan seberapa besar peran trait kepribadian conscientiousness dan tujuan dan norma sekolah yang dipersepsi oleh siswa memberikan kontribusi pada munculnya perilaku perundungan di sekolah.

Tabel 3.

Model Regresi Trait Conscientiousness dan Tujuan dan Norma Sekolah sebagai Prediktor terhadap Perundungan

\begin{tabular}{lcccc}
\hline \multicolumn{1}{c}{ Prediktor } & $\boldsymbol{r}$ & $\boldsymbol{R}^{2}$ & Adjusted $\boldsymbol{R}^{2}$ & Std. Error of the Estimate \\
\hline $\begin{array}{l}\text { Conscientiousness } \\
\begin{array}{l}\text { School Goal } \\
\text { and Norms }\end{array}\end{array}$ & .205 & .042 & .040 & 10.815 \\
$\begin{array}{l}\text { Conscientiousness \& } \\
\text { School Goal \& Norms }\end{array}$ & .194 & .038 & .036 & 10.838 \\
\hline
\end{tabular}

Pada tabel 3 di atas terlihat bahwa bahwa trait conscientiousness memberikan kontribusi sebesar 4.2 persen terhadap pencegahan perilaku perundungan pada siswa dan sisanya sebesar 93.8 persen disumbang oleh variabel lain di luar trait conscientiousness. Hasil uji regresi di atas juga menunjukkan bahwa peran tujuan dan norma sekolah terhadap pencegahan perundungan adalah sebesar 3.8 persen. Selebihnya sebesar 96.2 persen disumbangkan oleh variabel lain di luar variabel tujuan dan norma sekolah. Secara bersama-sama, kedua variabel ini yaitu trait kepribadian conscientiousness dan tujuan dan norma sekolah memberikan kontribusi sebesar 5.8 persen terhadap pencegahan perundungan di sekolah. Selebihnya sebesar 94.2 persen ditentukan oleh variabel lain di luar kedua variabel tersebut yang diprediksikan turut berperan dalam pencegahan perundungan. 


\section{DISKUSI}

Hasil penelitian ini menyimpulkan bahwa terjadinya perundungan tidak terlepas dari sisi kepribadian pelakunya, terutama trait yang berkaitan dengan conscientiousness. Ciri kepribadian tertentu akan mendukung siswa untuk terhindari dari perilaku perundungan. Conscientiousness dalam temuan ini memiliki kontribusi yang negatif terhadap perundungan. Individu yang memiliki dorongan untuk mencapai prestasi, patuh pada aturan, serta memiliki rasa tanggung jawab akan terhindar untuk menjadi pelaku perundungan. Hasil temuan ini sejalan dengan penelitian Mathisen, Einarsen, dan Mykletun (2011) pada lingkungan kerja bahwa rendahnya trait conscientiousness akan membuat individu cenderung menjadi pelaku perundungan. Hasil penelitiannya menyimpulkan bahwa individu yang memiliki trait conscientiousness yang rendah akan terlihat kurang gigih dalam berusaha serta meraih prestasi di lingkungannya. Mereka umumnya juga menjadi individu yang kurang terorganisasi dalam menyelesaikan pekerjaan-pekerjaannya dan kurang bertanggung jawab pada tugasnya.

Trait conscientiousness ditandai oleh faset-faset kompetensi (competence), keteraturan (order), ketaatan (dutifulness), berusaha mencapai prestasi (achievement striving), disiplin (selfdiscipline), dan penuh pertimbangan (deliberation). Individu dengan trait conscientiousness yang kuat adalah individu yang memiliki ciri disiplin, patuh pada aturan, rasa kompeten melakukan tugas, dan tanggung jawab pada pekerjaan dan apa yang dilakukannya (McCrae \& Costa, 2003). Dalam kaitannya dengan perundungan, maka dapat dipahami bila siswa-siswa yang memiliki trait conscientiousness yang kuat akan menjaga dirinya untuk tidak melakukan perundungan karena siswa tersebut menyadari bahwa perundungan adalah perilaku yang tidak sesuai dengan norma sosial.

Hasil uji regresi di atas menggambarkan besarnya kontribusi trait conscientiousness terhadap pencegahan perundungan. Hal tersebut berarti sekolah perlu menumbuhkembangkan trait conscientiousness yang dimiliki siswa sehingga siswa di sekolah mampu tampil sebagai individu yang patuh pada aturan, bertindak sesuai prosedur, serta menjunjung tinggi tanggung jawab. Program-program pendidikan yang dirancang untuk siswa perlu dipastikan akan membuat siswa terdorong untuk mematuhi aturan serta memiliki rasa tanggung jawab. Siswa-siswa yang tampil dengan trait conscientiousness yang kuat dapat dijadikan contoh bagi siswa lainnya, misalnya 
dengan memberikan penghargaan khusus pada program tertentu, sehingga dapat menjadi panutan bagi siswa lain untuk mencontoh hal yang serupa.

Peran iklim sekolah berupa tujuan dan norma sekolah mengindikasikan pentingnya tujuan dan norma yang berlaku di sekolah ditegakkan sehari-hari dalam pelaksanaannya. Norma sekolah yang mengatur tata kelola warga sekolah, termasuk di antaranya: keharusan untuk menghormati satu sama lain, saling menghargai, menegakkan disiplin, dan saling bekerja sama, merupakan halhal yang akan mendukung siswa untuk tidak terlibat dalam perundungan. Hal ini sejalan dengan penelitian Ryan (2009) yang menyatakan bahwa bila aturan di sekolah diberlakukan secara transparan maka akan memiliki pengaruh terhadap terbentuknya perilaku siswa.

Berdasarkan data yang dihimpun penulis terhadap SMA-SMA yang menjadi partisipan penelitian ini merupakan SMA Negeri. Tujuan dan norma sekolah disosialisasikan secara berkala kepada para siswa dan warga sekolah lainnya. Hasil wawancara maupun observasi juga menunjukkan bahwa sekolah-sekolah ini cukup tegas menindak pelanggaran yang dilakukan oleh siswanya, seperti siswa yang tidak menggunakan seragam yang sesuai dengan aturan sekolah, terlambat hadir di sekolah, serta akan diterapkannya sanksi bagi siswa yang melakukan perundungan terhadap temannya, dan sebagainya.

Bentuk sosialisasi norma dan tujuan sekolah menjadi hal yang bersifat konkret dalam seharihari, misalnya dalam bentuk memberikan kesempatan untuk berkembang secara luas pada siswa melalui sejumlah kegiatan, seperti ekstra kurikuler, ataupun sejumlah kegiatan pembelajaran di sekolah, sehingga siswa berlatih untuk saling bekerja sama, bersikap terbuka, saling menghargai, dan juga bertangung jawab terhadap tugas, maupun terlatih untuk bersikap saling menghargai teman-temanya. Penegakkan aturan dan norma sekolah bagi siswa memiliki peran penting untuk meminimalisir munculnya perundungan. Sejalan dengan hal ini, Gregory dkk. (2010) menyatakan bahwa sekolah yang menerapkan disiplin yang bersifat autoritatif (authoritatif school discipline) ditandai oleh struktur aturan yang kuat, serta terdapat dukungan emosi yang kuat kepada siswanya, diketahui memiliki korelasi yang negatif dengan terjadinya perundungan di sekolah. Artinya, peraturan dan norma yang jelas di sekolah akan mendukung remaja untuk lebih disiplin, teratur, dan bertanggung jawab pada tindakannya. 


\section{SIMPULAN DAN SARAN}

\section{Simpulan}

Perundungan di sekolah adalah fenomena yang ironis. Sebagai lembaga pendidikan, sekolah adalah agen moral yang membina para siswa agar memiliki perilaku normatif (Hoffman, 2010). Mencermati hal tersebut, maka sudah seharusnya pengembangan karakter maupun sifat positif siswa serta penegakkan aturan di sekolah mendapatkan perhatian dari para pendidik, orang tua, siswa yang bersangkutan, maupun masyarakat pada umumnya. Siswa dengan trait conscientiousness yang kuat akan memersepsikan perundungan sebagai perilaku yang melanggar kaidah normatif. Pendekatan perundungan dengan menguji pengaruh trait conscientiousness ini juga diharapkan dapat memperkaya literatur-literatur sebelumnya mengenai perundungan yang dikaitkan dengan pengembangan nilai-nilai moral maupun karakter. Selain karakter kepribadian di atas, aspek lain yang perlu ditekankan adalah pentingnya sekolah menegakkan aturan dan norma yang sudah disepakati sehingga dapat menjadi panduan bagi warga sekolah dalam menjalankan interaksinya sehari-hari. Sekolah yang disiplin dengan aturan yang jelas, pemberian sanksi bagi pelanggaran dan sebaliknya pemberian penghargaan bagi prestasi, memraktikkan sikap yang terpuji akan mendorong siswa untuk berlomba-lomba mengedepankan perilaku yang positif. Dalam hal ini, guru, pimpinan, maupun staf admininstrasi sekolah perlu menjadi contoh utama dalam penegakan disiplin maupun sikap yang positif, sehingga siswa dapat terpacu untuk menginternalisasi peraturan tersebut untuk diri mereka.

Sebagai kesimpulan, dapat dinyatakan bahwa, pertama, trait kepribadian conscientiousness memiliki pengaruh terhadap pencegahan perundungan sehingga pengembangan trait kepribadian ini perlu difasilitasi oleh sekolah. Walaupun trait bersifat menetap, tetapi hingga usia remaja trait masih berada dalam proses yang dinamis, sehingga lingkungan akan turut berpengaruh pada pembentukannya. Kedua, iklim sekolah yang positif yang ditandai dengan tegaknya aturan, norma dan tujuan sekolah akan memberikan kepastian kepada siswa untuk berperilaku sesuai aturan. Hal tersebut juga sekaligus menandakan bahwa sekolah mampu membangun suasana psikologis yang sehat, Ketiga, sebagai lembaga pendidikan, sekolah sudah seharusnya tidak hanya berfokus kepada pencapai prestasi kognitif semata, tetapi juga pengembangan karakter positif yang perlu ditekankan sesuai dengan arah tujuan pendidikan yang saat ini sedang gencar digaungkan oleh pemerintah maupun kalangan pendidik lainnya. 


\section{Saran Teoretis}

Saran teoretis yang dapat diberikan untuk penelitian selanjutnya adalah mengembangkan metode penelitian tidak hanya secara kualitatif, namun juga menggunakan metode kualitatif; atau lebih baik lagi bila mengombinasikan keduanya (mixed-methods). Hal ini dikarenakan fenomena perundungan merupakan variabel yang perlu digali mendalam terkait dengan aturan-aturan normatif yang melingkupinya. Penggalian data menggunakan metode kualitatif diharapkan dapat memperkaya hasil penelitian secara lebih mendalam. Kedua, perundungan pada penelitian ini dilakukan terhadap siswa setingkat SMA. Mengingat perundungan merupakan fenomena yang bahkan dapat ditemui di jenjang pendidikan yang lebih rendah, seperti SMP bahkan SD, maka ada baiknya penelitian dilakukan pada siswa yang lebih rendah. Ketiga, perundungan memiliki beberapa tipe, seperti tipe fisik, tipe verbal dan non verbal. Disarankankan untuk penelitian selanjutnya dapat mengupas perbedaan tipe perundungan tersebut dikaitkan dengan variabel penelitian lainnya.

\section{Saran Praktis}

Pertama, sebagai remaja akhir, siswa SMA membutuhkan bimbingan dan dukungan guru dalam pencegahan perundungan. Pelatihan yang bersifat aplikatif mengenai pengembangan karakter positif bagi maupun siswa perlu difokuskan dan diberikan secara berkala. Pelatihan dapat dititipkan pada kegiatan ekstrakurikuler. Misalnya pada kegiatan pramuka dengan fokus mengasah kemampuan siswa mengembangkan sikap setia kawan, bertanggung jawab dan kerja sama, ataupun dalam materi pembelajaran di sekolah, seperti mata pelajaran PPKN dan agama. Kedua, responden penelitian ini adalah siswa pada jenjang SMA yang berasal dari sekolah Jakarta dengan karakteristik tertentu. Penelitian selanjutnya dapat dilakukan pada siswa dari berbagai kota besar di Indonesia, maupun kota-kota lainnya untuk memperoleh gambaran komprehensif mengenai fenomena perundungan pada siswa dewasa ini. Ketiga, sekolah-sekolah dengan ciri khusus, seperti sekolah kejuruan, sekolah keahlian khusus, sekolah kedinasan, maupun sekolah berasrama (boarding school), merupakan sekolah-sekolah dengan nuansa khusus yang menarik untuk didalami. Penelitian pada sekolah-sekolah tersebut dapat menjadi informasi yang berguna bila dikaitkan dengan fenomena perundungan. 


\section{REFERENSI}

Arora, T. (1994). Measuring bullying with the 'Life in School' checklist. Pastoral Care, 12, 11-16.

Crapanzano, A. M. (2010). Understanding bullying participant roles: Stability across school years and personality and behavioral correlates. Ditemu kembali dari https://scholarworks.uno.edu/cgi/viewcontent.cgi?referer=https://www.google.co.id/\&httpsr edir $=1 \&$ article $=1107 \&$ context $=$ td

Domenico, S. I., Quitasol, M. N., \& Fournier, M. A. (2015). Ratings of conscientiousness from physical appearance predict undergraduate academic performance. Journal of Nonverbal Behavior, 39(4), 339-353. doi: 10.1007/s10919-015-0213-9

Dunn, S. T. M. (2009). Upstanders: Student experiences of intervening to stop bullying (Disertasi). Ditemu kembali dari ProQuest Dissertations \& Theses Global (No. 55337).

Feist, J., \& Feist, G. (2008). Theories of Personality (7th ed.). New York, NY: McGraw-Hill.

Gregory, A., Cornell, D., Fan, X., Sheras, P., Shih, T., \& Huang, F. (2010). Authoritative school discipline: High school practices associated with lower bullying and victimization. Journal of Educational Psychology, 102(2), 483-496. doi: 10.1037/a0018562

Guilford, J. P. (1978). Fundamental Statistics in psychology and education. New York, NY: McGraw-Hill.

Hoffman, B. (2010). Cooperative learning, character education, conflict resolution among eighth graders, their teacher intervention with bullying and their experiences with cyber, physical, and relational bullying (Disertasi). Ditemu kembali dari UMI Database (UMI No. 3420453).

Jimerson, S. E., Swearer, S. M., \& Espelage, D. L. (2009). Handbook of bullying in school: An international perspective. New York, NY: Routledge.

Kenneth, W. M., Barbara, A. G., Scott, W. R., \& Duane, M. I. (2008). How effective are school bullying intervention programs? A meta-analysis of intervention research. School Psychology Quarterly, 23(1), 26-42.

Kerlinger, F. N., \& Lee, H. B. (2006). Asas-asas Penelitian Behavioral. Yogjakarta: Gadjah Mada University Press.

KPAI: Kasus bullying di sekolah meningkat selama 2015. (2015). Republika Online. Ditemu kembali dari http://nasional.republika.co.id/berita/nasional/umum/15/12/30/o067zt280-kpaikasus-bullying-di-sekolah-meningkat-selama-2015. 
Mathisen, G. E., Einarsen, S., \& Mykletun, R. (2011). The relationship between supervisor personality, supervisors' perceived stress and workplace bullying. Journal of Business Ethics, 99(4), 637-651. doi: 10.1007/s10551-010-0674-Z

McCrae, R. R., \& Costa, P. T. (2003). Personality in adulthood: A five-factor theory perspective (2nd ed.). New York, NY: The Guilford Press.

Muth, T. J. (2012). Parenting and peer bullying: Parents' and adolescents' beliefs, communication, behavior and strategies. Ottawa, Canada: Published Heritage Branch.

Paramo, J. A. (2012). School bullying: A systematic review of the literature (Tesis). Ditemu kembali dari UMI Database (UMI No. 1511379).

Prasetyo, A. B. E. (2011). Bullying di sekolah dan dampaknya bagi masa depan anak. Journal Psikologi, 4(1), 1-8.

Rahmawati, S. W. (2016a). Salah kaprah istilah bullying. Buletin Konsorsium Psikologi Ilmiah Nusantara, 2(2). Ditemu kembali dari http://buletin.k-pin.org/index.php/arsip-artikel

Rahmawati, S. W. (2016b). Peran iklim sekolah terhadap perundungan. Jurnal Psikologi, 43(2), 167-180. Ditemu kembali dari https://jurnal.ugm.ac.id/jpsi/article/view/12480/15175

Rahmawati, S. W. (2017). Bullying siswa di sekolah menengah atas: Peran holistic parenting dan iklim sekolah terhadap bullying melalui variabel mediasi trait kepribadian lima besar (Disertasi tidak dipublikasikan). Universitas Padjadjaran, Indonesia.

Rahmawati, S. W., Iskandar, T. Z., Setiono, K., \& Abidin, Z. (2014). Tinjauan studi pendahuluan trait kepribadian lima besar dan perundungan. Penelitian tidak dipublikasikan.

Ryan, W. (2009). Links between school climate and bullying: A study of two tribes schools. Ditemu kembali dari https://ruor.uottawa.ca/bitstream/10393/29846/1/NR59517.PDF

Sullivan, K. (2000). The anti-bullying handbook. Oxford, UK: Oxford University Press.

Summers, K. H. (2008). The relationship among bullying participant roles, social support, and school climate (Disertasi). Ditemu kembali dari UMI Database (UMI No. 3335063).

Sutherland, A. E. (2010). The roles of school climate and peers in bullying. Ditemu kembali dari https://qspace.library.queensu.ca/bitstream/handle/1974/6057/Sutherland_Alexandra_E_201 009_PhD.pdf?sequence $=1 \&$ is Allowed=y

Ttofi, M. M., Farrington, D. P., Losel, F., \& Loeber, R. (2011). Do the victims of school bullies tend to become depressed later in life? A systematic review and meta-analysis of longitudinal studies. Journal of Aggression, Conflict and Peace Research, 3(2), 63-73. 
Waasdorp, T. E., Bradshaw, C. P., \& Duong, J. (2011). The link between parents' perceptions of the school and their responses to school bullying: Variation by child characteristics and the forms of victimization. Journal of Educational Psychology, 103(2), 324-335.

Wolker, D., \& Lereya, S. T. (2015). Long-term effect of bullying. Archives of Disesea in Childhood, 100 (9), 879-885. 